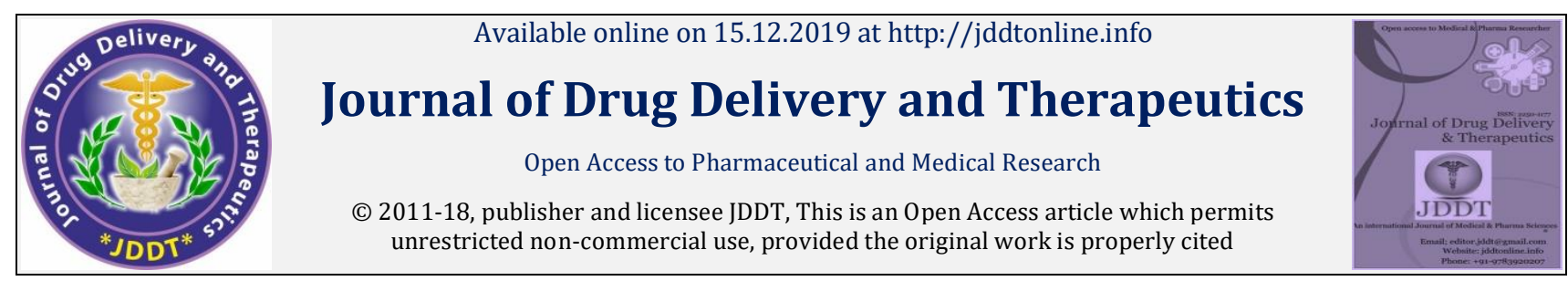

Open Access

Research Article

\title{
Isolation of Phytochemical and Evaluation of Antiasthmatic Potency of Ficus racemosa
}

\author{
Shinde Suvarna*, Rao Priya S., Dighe Santosh B., Dukare T. P. \\ Department of Pharmacognosy, Pravara Rural college of Pharmacy, Pravaranagar, Tal- Rahata Dist-Ahmednagar, India
}

\begin{abstract}
The Present study reports important secondary metabolites present in Ficus racemosa The Ficus racemosa belong to the family Moraceae, it is popularly known as Glomerata, Cluster fig tree as well as 'Udumbara' in Marathi. Various plant parts such as bark, root, leaf, fruits are used as astringent, carminative, anti-dysentery, diabetes, leucoderma, antiasthmatic, hepatoprotective, antioxidant. The powdered Bark was subjected for extraction by using ethanol. These extract were evaluated for detection of various secondary metabolites, like Steroids, Glycosides, tannins, Terpenoids, Alkaloids, Flavonoids. This work evaluated the stem bark of this plant for its Phytochemical and Antiasthmatic activity.
\end{abstract}

Keywords: Ficus racemosa, Steroids, Antiasthmatic, Moraceae

Article Info: Received 16 Oct 2019; Review Completed 23 Nov 2019; Accepted 30 Nov 2019; Available online 15 Dec 2019

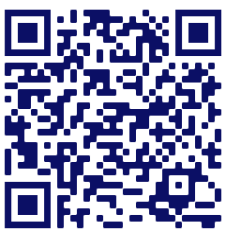

Cite this article as:

Shinde S, Rao PS, Dighe SB, Dukare TP, Isolation of Phytochemical and Evaluation of Antiasthmatic Potency of Ficus racemosa, Journal of Drug Delivery and Therapeutics. 2019; 9(6-s):107-109 http://dx.doi.org/10.22270/jddt.v9i6-s.3773

*Address for Correspondence:

Ahmednagar, India

Shinde Suvarna, Department of Pharmacognosy, Pravara Rural college of Pharmacy, Pravaranagar, Tal- Rahata Dist-

\section{INTRODUCTION}

Medicinal plants are of great importance in the field of medicine and cure of diseases. Practical experience and several modern research studies have shown that therapy using plant is better than using synthetic chemicals. There is still large number of medicinal plant in which all active constistuents have not yet been investigated even though their medicinal effect is established by folklore and traditional system of medicine ${ }^{1}$.

The present definition of asthma is a chronic inflammatory di sease of the airways with reversible type of airway obstruction, either spontaneously or with therapy.

Asthma is a complex disease characterized by bronchial hyperresponsiveness, inflammation, mucus production and intermittent airway obstruction ${ }^{2}$.

In susceptible individual, inflammation causes recurrent episodes of wheezing, breathlessness (shortness of breath), chest tightness \& coughing, particularly at night or early in the morning, otherwise after exposure to an allergen, cold air, exercise and when emotional ${ }^{3}$.

\section{MATERIAL AND METHODS}

Collection : Fresh sample of bark of Ficus racemosa were collected from Ahmednagar district, Loni, cleaned and dried at room temperature in shade, away from direct sunlight and coarsely powdered in grinder and powder material was passed through 120 mesh to remove fine powders and coarse powder was used for extractions.

Authentication: Mr. C.R. Jadhav, Botanists, Botanical Survey of India, Koregaon Road, Pune, authenticated plant by comparing morphological features and a sample voucher specimen of plant was deposited for future reference (BSI/WRC/IDEN.CER./2019/H3).

Extraction: The bark of Ficus racemosa was collected and dried in the shade. Then the dried material is pulverized in grinder. The powdered material was passed through 120 mesh sieve to remove fine powder and course powder was used for extraction ${ }^{4}$.

Animals: Male albino mice (Swiss strain) weighing 25-28 g were housed under standard laboratory conditions, in groups of six each. The animal had free access to food and water. The ethical committee of the institute approved the protocol of the study.

Drugs and Chemicals: The following drugs and chemicals were used. Drugs: Clonidine (Unichem, India) and Chlorheniramine maleate purchased from commercial source.

Chemicals: Ethanol AR, tween 80 AR.

Antiasthmatic activity:

Species \& Strain: Mice 
Gender: Either sex

Swiss albino mice will be divided into three groups $(n=6)$ as follows:

Group I: Vehicle control [Maintained on regular mice food and drinking water ad libitum and received distilled water (0.5 ml/100 gm p.o.).]

\section{Group II- Standard}

\section{Group III: Ethanol extract}

Statistical Analysis: The data is presented as mean \pm SEM. The data was analyzed by one-way ANOVA followed by Dunnett's test. Prism Graph pad 3 was used for statistical analysis. ${ }^{*} \mathrm{P}<0.05$ was considered significant.

\section{1) Clonidine induced catalepsy in mice}

Albino mice Will be divided into Three groups $(\mathrm{n}=6)$.Control group received distilled water $(10 \mathrm{ml} / \mathrm{kg})$ and Standard group received chlorpheniramina malate $(10 \mathrm{mg} / \mathrm{kg}$, i.p.). And group $3^{\text {rd }}$ will be received single dose of ethanolic extract. All the groups will be received Clonidine $(1 \mathrm{~g} / \mathrm{kg}$ s. c.) $1 \mathrm{hr}$ after the drug administration and the duration of catalepsy will be measured at $(15,30,60,90,120,150$ and $180 \mathrm{~min})^{5,6}$.

\section{2) Mast cell Degranulation}

Mice will be divided in three groups, $(\mathrm{n}=6)$.the 3 days drug treatment schedule will be followed. Control group will be received distilled water $(10 \mathrm{ml} / \mathrm{kg}$, p. o.)and Standard group was treated with Disodium cromaglycate $(0.5 \mathrm{mg} / \mathrm{kg}$, I.p.) Group-3rd will be treated with ethanolic extract of Ficus racemosa $\left(100 \mathrm{mg} / \mathrm{kg}\right.$ p.o.). On $4^{\text {th }}$ day, each animal will be injected with $4 \mathrm{ml} / \mathrm{kg} 0.9 \%$ Nacl solution into peritoneal cavity. The abdomen will be gently massaged for few mints. The peritoneal cavity will be carefully opened and fluid containing mast cells will be aspirated and collected in testtube containing $8 \mathrm{ml}$ of animal cell culture media RPMI-1640 buffer solution (7.2-7.4).The mast cell will be then washed with same buffer solution centrifugation at a speed of 400$500 \mathrm{rpm}$ and the pellet of mast cells will be collected. Then $0.5 \mu \mathrm{g} / \mathrm{ml}$ clonidine solution will be added to the mast cell suspension and incubated at $37^{\circ} \mathrm{C}$ in a water bath in $10 \mathrm{~min}$. Later day will be stained with $1 \%$ toludine blue die and observed under high power microscope(400X). Total 100 cells will be counted from different visual areas and percent protection against clonidine induced mast cell degranulation will be calculated 7,8 .

\section{RESULT}

\section{1) Clonidine induced catalepsy in mice}

Table No. 1): Effect of various extracts of F. racemosa bark (10 mg/kg, p.o.) on clonidine-induced catalepsy in mice.

\begin{tabular}{|c|c|c|c|c|c|c|c|c|}
\hline \multirow{2}{*}{ Group } & \multicolumn{9}{|c|}{ Duration of catalepsy (sec) at Mean \pm SEM } \\
\cline { 2 - 9 } & $\mathbf{0 ~} \mathbf{~ m i n}$ & $\mathbf{1 5} \mathbf{~ m i n}$ & $\mathbf{3 0} \mathbf{~ m i n}$ & $\mathbf{6 0} \mathbf{~ m i n}$ & $\mathbf{9 0} \mathbf{~ m i n}$ & $\mathbf{1 2 0} \mathbf{~ m i n}$ & $\mathbf{1 5 0} \mathbf{~ m i n}$ & $\mathbf{1 8 0} \mathbf{~ m i n}$ \\
\hline Control & $24.6 \pm$ & $24.4 \pm$ & $24.8 \pm$ & $25.2 \pm$ & $25.3 \pm$ & $25.4 \pm$ & $25.5 \pm$ & $25.7 \pm$ \\
& 0.19 & 0.20 & 0.18 & 0.20 & 0.29 & 0.23 & 0.23 & 0.20 \\
\hline Standard & $27.8 \pm$ & $27.6 \pm$ & $30.3 \pm$ & $29.6 \pm$ & $28.2 \pm$ & $36.7 \pm$ & $36.8 \pm$ & $37.3 \pm$ \\
& $0.24^{* * *}$ & $0.38^{* * *}$ & $0.31^{* * *}$ & $0.19^{* * *}$ & $0.42^{* * *}$ & $0.18^{* * *}$ & $0.40^{* * *}$ & $0.39^{* * *}$ \\
\hline Test & $25.8 \pm$ & $26.5 \pm$ & $28.9 \pm$ & $28.1 \pm$ & $26.6 \pm$ & $34.8 \pm$ & $35.1 \pm$ & $36.0 \pm$ \\
& $0.31^{* * *}$ & $0.37^{* * *}$ & $0.24^{* * *}$ & $0.26^{* * *}$ & $0.27^{*}$ & $0.31^{* * *}$ & $0.33^{* * *}$ & $0.61^{* * *}$ \\
\hline
\end{tabular}

All the data are expressed as mean \pm SEM, $\mathrm{n}=\mathrm{six}$, Control = Vehicle, d.w. $(10 \mathrm{ml} / \mathrm{kg}$, p.o.). Std. = Chlorpheniramine maleate $(10 \mathrm{mg} / \mathrm{kg}$, I.p.). Test= Ethanolic extract of Ficus racemosa $(10 \mathrm{mg} / \mathrm{kg}$, p.o.). = Ethanolic extract of Ficus racemosa Statistical analysis done by using ANOVA followed by Dunnett's test. ${ }^{* * *} \mathrm{P}<0.001$ considered significant compared to control group.

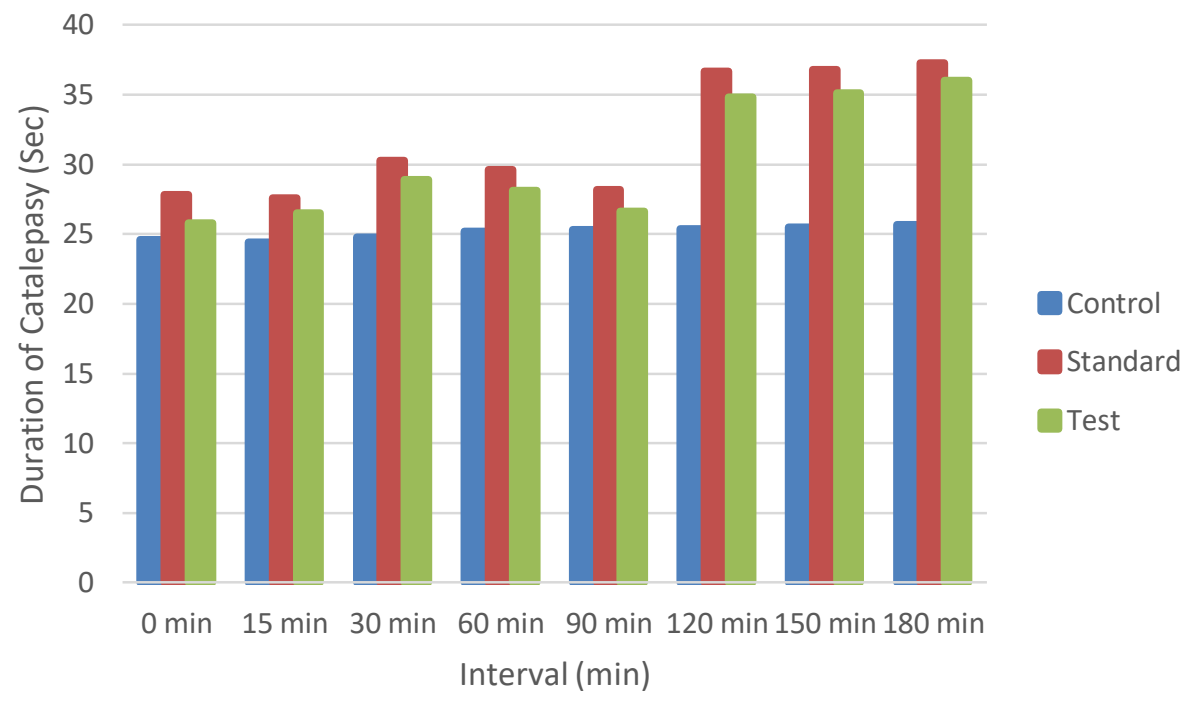

Figure 1). Effect of various extracts of Ficus racemosa bark $(10 \mathrm{mg} / \mathrm{kg}$, p.o.) on clonidine-induced catalepsy in mice.

All the data are expressed as mean $\pm \mathrm{SEM}, \mathrm{n}=$ six in each group. ${ }^{* * *} \mathrm{P}<0.001$ compared to control (One way ANOVA followed by Dunnett's test).Where; ETE - Ethanol extract. 
2) Mast cell Degranulation

Table No. 2) Effect of Ethanolic extract of Ficus racemoa on mast cell degranulation in mice.

\begin{tabular}{|l|l|l|l|}
\hline Groups & \% of complete granulation & $\begin{array}{l}\text { \% of partial of incomplete } \\
\text { granulation }\end{array}$ & of non granulation \\
\hline Control & 28 & 24 & $48^{*}$ \\
\hline Standard & 22 & 20 & 58 \\
\hline ETH(100) & 29 & 23 & 47 \\
\hline
\end{tabular}

$\mathrm{n}=5$, Values are in Mean \pm SEM. Control = Vehicle, d.w. (10 ml $/ \mathrm{kg}$, p.o.). Std. = Disodium cromaglycate $(10 \mathrm{mg} / \mathrm{kg}$, p.o.).= Ethanolic extract of Ficus racemosa (10 mg/kg, p.o.). Statistical analysis done by using ANOVA followed by Dunnett's test.

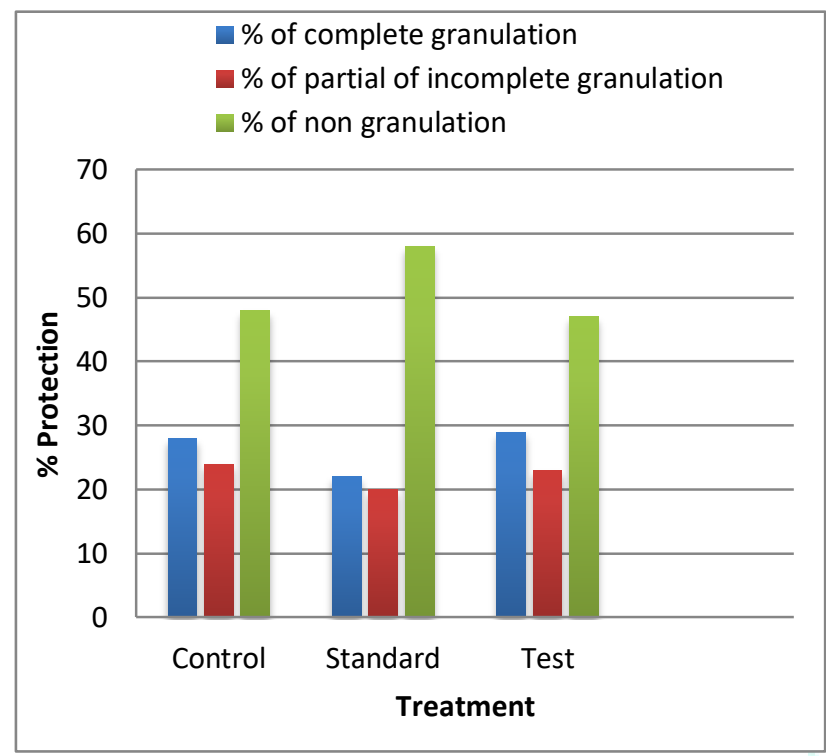

Figure 2). Effect of various extracts of Ficus racemosa bark (10 mg/kg, p.o.) on Mast cell degranulation in mice.

\section{DISCUSSION}

Antihistaminic, antiallergic, stabilizing mast cell and charact eristics of bronchorelaxation are crucial in drug for the thera py of asthma ${ }^{9}$. Thus, appropriate models have been used in this research to screen the extracts for the above mentioned characteristics ${ }^{10}$.

The ethanolic extract significantly inhibited the clonidine induced catalepsy. The inhibition of clonidine induced catalepsy by Ficus racemosa may be due to the potential to antagonize $\mathrm{H} 1$ receptor or inhibition of mast cell degranulation induced by clonidine ${ }^{11}$.

Present study showed dose dependent statistically significant stabilization of mast cell by ethanolic extract of Ficus racemosa.

\section{CONCLUSION}

As the Ethanol extract of Fracemosa Bark is having Clonidine-induced catalepsy and mast cell stabilizing property, it can be used in the treatment asthma ${ }^{12}$. $\beta$ sitosterol was identified form the Ethanol extract having antiasthmatic activity so we can say that the antiasthmatic activity of F.racemosa bark is may be due to presence of $\beta$ sitosterol.

\section{ACKNKOWLEDGEMENT}

We are thankful to Principal and management of Pravara Rural College of Pharmacy, Loni, for Providing the necessary facilities and Guidence for carrying out research work.

\section{REFERENCES}

1. Padam Singh, Yadav R. J. and Arvind Pandey, Utilization of indigenous system of medicine and homeopathy in India, Institute for research in medical statistics, Indian J Med Res, 137-142.

2. WHO. Quality Control Methods for Medicinal Plant Material. World Health Organization, Geneva, pp., 1992; 22-34

3. Rang H.P., Dale M.M., Pharmacology, Vth ed, Churchill Livingstone Publication, Edinburgh, pp. 2001; 340-351.

4. Mukharjee, P.K., Quality Control of Herbal Drugs an approach to Evaluation of Botanicals, 1st ed, Business Horizons' Publication, 2002; 133-492.

5. Deepak Kumar, D.N. Prasad, Jyoti Parkash, S. P. Bhatnagar, Dinesh Kumar, antiasthmatic activity of ethanolic extract of Aerva lanata Linn., Pharmacologyonline 2009; 1075-1081.

6. Dnyaneshwar J. Taur \& Ravindra Y. Patil, Antihistaminic activity of Abrus precatorius using clonidine induced catalepsy in mice, Orient Pharm Exp Med., 2012; 12:11-14.

7. Geetha V.S, Viswanathan S, Kameswaran L., Comparison of total alkaloids of Tylophora indica and disodium chromoglycate on mast cell stabilization. Indian Journal of Pharmacology.1981; 199-201.

8. Gupta P.P, Srimal R.C, Verma N, Tandon J.S. Passive cutaneous anaphylactic inhibitory and mast cell stabilizing activity of coleonol and its derivative. Indian Journal of Pharmacology 1994; 150-153.

9. Jadhav J. H. Balsara, J.J, Chandorkar, Involvement of histminergic mechanisms in the cataleptogenic effect of clonidine in mice, J. Pharm Pharmacol, 1983; 671-673.

10. Mulye, M.P., Balsara J.J., Involvement of histminergic mechanisms in the cataleptogenic effect of clonidine in mice, J. Pharm Pharmacol, 1983; 671-673.

11. Lakadwala A.D., Dadkar N.K., Dohadwala A.N., Action of clonidine on mast cells of rats. Journal of Pharmacy and Pharmacology 1980; 790-791.

12. Nirmal S.A., Pal S.C., Mandal S.C., Antiasthmatic activity of Nyctanthes arbortristis leaves. Latin American Journal of Pharmacy. 2011; 654-60.

13. Ravindra G.M. \& Avinash S.D., A review on herbal antiasthmatics, Orient Pharm Exp Med., 2011; 11: 77-90.

14. Prakash Deep, Amrit K.S., Md. Tahir Ansari, Prashant Raghav, Pharmacological Potentials of Ficus racemosa - A Review, Int J. Pharm. 2013; 22(1): 29-34.

15. Krishna Murti, Upendra Kumar, Vijay Lambole, Sandip P.B. Mayank A. P., pharmacological properties of ficus racemosa - a review, Pharmacologyonline, 2010; 2: 802-807.

16. Baby Joseph, S. J.R., Phytopharmacological properties of Ficus racemosa Linn an overview, 2010; 134-137. 